\title{
Assessing Productivity and Profitability of Hybrid Rice With Site Specific Nutrient Management in Mid Western Terai, Nepal
}

\author{
Samikshya Acharya (Corresponding author) \\ Institute of Agriculture and Animal Science, Prithu Technical College, Tribhuvan University, \\ Nepal \\ E-mail: acharyasamikshya727@gmail.com
}

\begin{abstract}
Binita Mahara
Institute of Agriculture and Animal Science, Prithu Technical College, Tribhuvan University, Nepal

E-mail: maharabinita5@gmail.com

Lal Prasad Amgain

Institute of Agriculture and Animal Science, Rampur Campus, Tribhuvan University, Nepal E-mail: amgainlp@gmail.com
\end{abstract}

Krishna Aryal

Institute of Agriculture and Animal Science, Prithu Technical College, Tribhuvan University, Nepal

E-mail: krish.aryal2014@gmail.com

Received: April 10,2019 Accepted: June 20, $2019 \quad$ Published: June 22, 2019

Doi: 10.5296/jab.v7i2.14959 URL: https://doi.org/10.5296/jab.v7i2.14959 


\section{Abstract}

Rice (Oryza sativa L.) is a dominant staple food crop of Nepal which production and productivity is significantly declining compared to several years due to inappropriate nutrient management practices. A field experiment was conducted at Lamahi, Dang to evaluate the performance of hybrid rice(US-305) under rain fed condition with five precision nutrient management practices [Viz: Nutrient Expert ${ }^{\circledR}$-Rice (NE) recommendation; Leaf Color Chart (LCC) N and Nutrient Expert (P and K); Nutrient Expert (N) and Farmers Fertilizer Practices (P and K); Farmers Fertilizer Practices (FFP) and Government Recommendation (GR)] replicated four times in RCBD design during June to October, 2018. The experimental finding showed that SSNM based Nutrient Expert® -Rice (NE) recommendation gave higher grain yield (6.36 ton ha- ${ }^{-1}$ ) and straw yield (12.62 ton ha- ${ }^{-1}$ ) which leads to highest gross return (NRs 242,498) and B: C ratio (3.08). Between the treatments Nutrient Expert® -Rice (NE) recommendation was excellent to growth parameters like plant height, crop growth rate, relative growth rate and leaf area index over FFP. Further, Nutrient Expert ${ }^{\circledR}$-Rice (NE) recommendation gave significantly higher effective tiller $\mathrm{m}^{-2}(354.50)$, panicle length (26.31), panicle weight (81.50), filled grain (390) and fertility (87.56\%) over FFP. Nutrient Expert® -Rice (NE) recommendation has increased the grain yield by $23.97 \%$ with yield difference of 1.23 ton $\mathrm{ha}^{-1}$ and straw yield by $39.44 \%$ with yield difference of 3.57 ton $^{\text {ha }}{ }^{-1}$ in comparison with FFP. Hence the experiment concluded that site specific nutrient management recommendation that accounts Nutrient Expert ${ }^{\circledR}$-Rice and leaf color chart could be the practical decision tool for making authentic fertilizer recommendation.

Keywords: Farmers fertilizer practice, Government recommendation, Leaf Color Chart, Nutrient expert-Rice, Profitability

\section{Introduction}

Rice (Oryza sativa L.) a dominant staple food crop for more than half of world population and approximately 480 million metric tons of milled rice is produced annually (Muthayya et al., 2014). It's production and consumption are among the highest in Asian region of which China and India accounts for about 50\% (Doberman \& Witt, 2003).

In Nepal, rice is cultivated under different production environments (irrigated, rain-fed lowland and upland) and ecological regions (Terai and Inner Terai- 67 to 900 masl; Mid Hills - 1000 to 1500 masl; and High Hills - 1500 to 3050 masl) and dominates the country's crop sector. Almost half of the total cultivated area is devoted to rice annually and Terai shares majority of the country's rice output (MoAD, 2015). Rice is cultivated in approx. 1.5 million hectares of land with the production of 5.2 million tones and productivity of 3.53 ton $\mathrm{ha}^{-1}$ (MoAD, 2017). This low production and productivity of rice along with its increasing demand made the country to import rice from foreign countries. The recent official data of Government of Nepal revealed that Nepal imported rice of worth NRs 21.24 billion in 2017/18 (MOF, 2018). The possibility of expanding the area in future is very limited. To fulfill the upsurge demand, the farming has shifted from local variety to the hybrid varieties for higher yield (Heisey et al., 1998). Agronomic management and technological innovations are needed to address these issues at present. Yet, the productivity of hybrid rice is very low 
in developing countries highlighting the major constraint factor of the production technology i.e. proper fertilizer management.

Less possibility of promising technologies generated by agricultural research in our land, owing major improper fertilizer management resulted under or over fertilization. Fertilization as a blanket dose without considering site specific soil and weather condition has been recommended by government bodies and research station but yield of crop is directly affected by nutrient need of crop and nutrient content in soil (Janssen et al., 1990). Poor farmer are unaware about the fertilizer dose. So there is great opportunity in increasing productivity of rice decreasing yield gap to fulfill national demand through improved nutrient management, as there is a considerable gap between researcher managed fertilizer plots and farmer managed plots (Ladha et al., 2003).

Site specific nutrient management (SSNM) is the specific approach that advocates the optimum use of indigenous nutrients originating from soil, plant nutrients, manures and irrigation water focusing on balanced and crop need based nutrient application (Pampolino et al., 2007). Site-Specific Nutrient Management (SSNM) provides opportunities for timely application of fertilizer at optimal rates to fill the deficit between nutrient need of high yielding crop and nutrient supply from naturally occurring indigenous sources (Singh, 2004).

Nutrient Expert ${ }^{R}(\mathrm{NE})$ effortless, interactive and computer based tool with consistent $4 \mathrm{R}$ stewardship allows fertilizer with right source at right rate, right time and right place that works on principles of site specific nutrient management (Dobermann \& Witt, 2004). LCC is a simple, inexpensive low technology tool of SSNM that is well suited as an indicator of leaf $\mathrm{N}$ status for small scale farmers in Asia. It enables the application of $\mathrm{N}$ as per crop demand which enhances the $\mathrm{N}$ use efficiency in crops. The approach is known as real- time $\mathrm{N}$ management. This approach avoids the excessive $\mathrm{N}$ application by matching time and amount of fertilizers as per the plant need (IRRI, 2010). The research aims at utilizing the best way of sustained nutrient management practice in rainfed Mid Western Terai region of Nepal for higher rice production.

\section{Materials and Method}

The experiment was conducted during the rainy season of 2018 in farmer's field of Lamahi municipality, Dang district which geographically represents Mid-Western Terai of Nepal. The preliminary nutrient expert model questionnaire was prepared and interviewed with four different farmers to record the information about their existing nutrient management practices. The obtained information's were entered in NE Rice software and different doses of nitrogen through Urea, phosphorus through Diammonium Phosphate (DAP) and potassium through Murate of Potash (MOP) were recommended. LCC doses were calculated using leaf color chart at every ten days interval starting after ten Days After Transplanting (DAT). The experiment was laid out in Randomized Complete Block Design(RCBD) with five precision nutrient management practices [Viz: Nutrient Expert ${ }^{\circledR}$-Rice (NE) recommendation; Leaf Color Chart (LCC) N and Nutrient Expert (P and K); Nutrient Expert (N) and Farmers Fertilizer Practices ( $\mathrm{P}$ and K); Farmers Fertilizer Practices (FFP) and Government Recommendation (GR)] which were replicated four times. Each experimental plot is of size 
of $25 \mathrm{~m}^{2}$. The experimented variety was a hybrid variety (US 305). The seedlings were grown in nursery bed adopting farmers practice and were transplanted in the main field after 22 days maintaining the spacing of $25 \mathrm{~cm} \times 25 \mathrm{~cm}$. Fertilizer recommendations rate was differ for each assigned treatments. Harvesting was manually done at the second week of October. Various observations like plant height, effective tillers $\mathrm{m}^{-2}$, crop growth rate, relative growth rate, leaf area index, length and weight of panicle, test weight, tiller panicle conversion index, grain yield, straw yield, biological yield, harvest index was taken.

Comparison of attainable and observed yield and economics was done in between NE and FFP. Gross and Net revenue, B:C ratio, Partial factor productivity and Total Factor productivity were calculated for economic analysis. Data entry and analysis was done using excel and R-studio. ANOVA was performed at $0.05 \%$ level of significance.

Table 1. Treatment details of the experiment

\begin{tabular}{|c|c|c|}
\hline S.N. & Treatments & Fertilizer recommendation \\
\hline 1. & $\mathrm{NE}$ & 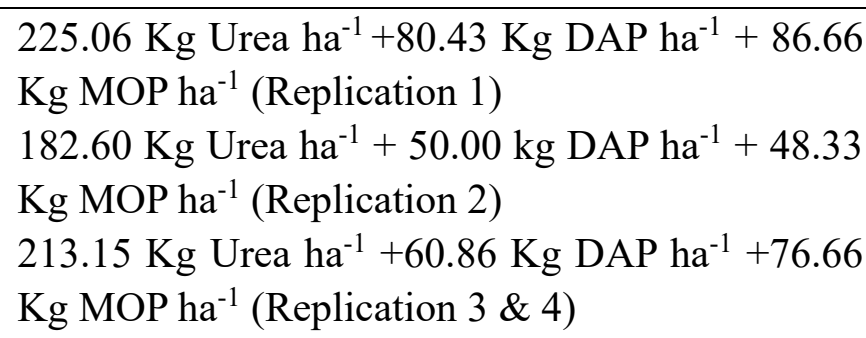 \\
\hline 2. & $\mathrm{LCC}(\mathrm{N})+\mathrm{P}$ and $\mathrm{K}(\mathrm{NE})$ & $\begin{array}{l}60.86 \mathrm{Kg} \text { Urea ha }{ }^{-1} \text { and as } \mathrm{P} \& \mathrm{~K} \text { calculated from } \\
\mathrm{NE}\end{array}$ \\
\hline 3. & $\mathrm{NE}(\mathrm{N})+\mathrm{P}$ and $\mathrm{K}(\mathrm{FFP})$ & $130.43 \mathrm{Kg}$ Urea ha ${ }^{-1}$ and $\mathrm{P}$ from farmer practice \\
\hline 4. & GR & $\begin{array}{l}\text { 166.36 Kg Urea ha-1 }+130.43 \mathrm{Kg} \text { DAP ha-1 } \\
66.67 \mathrm{~kg} \mathrm{MOP} \mathrm{ha}^{-1}\end{array}$ \\
\hline 5. & FFP & $\begin{array}{l}\text { As farmer practice, Urea } 30 \mathrm{~kg} \mathrm{ha}^{-1} \text {, DAP } 15 \mathrm{~kg} \\
\mathrm{ha}^{-1}\end{array}$ \\
\hline
\end{tabular}

Note. $\mathrm{NE}=$ Nutrient $\operatorname{export}{ }^{\circledR}, \mathrm{GR}=$ Government recommendation, FFP $=$ Farmers fertilizer Practice $\mathrm{LCC}=$ Leaf color chart

\section{Results and Discussions}

3.1 Growth Parameters (Plant height, Crop Growth Rate, Relative Growth Rate, and Leaf Area Index)

The different precision nutrient management practice showed significant effect on growth parameters such as plant height, crop growth rate, relative growth rate and leaf area index. Plant height was found to significantly higher in NE $(99.89 \mathrm{~cm})$ as compared to FFP (88.39) but are statistically at par with $\mathrm{LCC}(\mathrm{N})$ combined with $\mathrm{NE}(\mathrm{PK}), \mathrm{NE}(\mathrm{N})$ combined with FFP(PK) and GR. Similarly, Crop growth rate (3.56), relative growth rate (0.06), leaf area index (4.08) was significantly higher in NE followed by LCC (N) combined NE(PK) with 
reduced value observed in FFP respectively. The result is similar to Chaturbedi (2005) Budathoki et al. (2018) which reported that balanced application of NPK at a specific site gives higher value for growth parameters.

Table 2. Effect of different precision nutrient management on plant height, crop growth rate, relative growth rate, LAI in hybrid rice in Lamahi, Dang 2018

\begin{tabular}{|c|c|c|c|c|c|}
\hline Treatment & $\begin{array}{l}\text { Plant height } \\
(\mathrm{cm})\end{array}$ & $\begin{array}{l}\text { Crop growth } \\
\text { rate }\end{array}$ & $\begin{array}{l}\text { Relative growth } \\
\text { rate }\end{array}$ & $\begin{array}{l}\text { Leaf } \\
\text { Index }\end{array}$ & Area \\
\hline $\mathrm{NE}$ & $99.89^{\mathrm{a}}$ & $3.56^{\mathrm{a}}$ & $0.06^{\mathrm{a}}$ & $4.08^{\mathrm{a}}$ & \\
\hline $\mathrm{LCC}(\mathrm{N})+\mathrm{NE}(\mathrm{P}$ and $\mathrm{K})$ & $94.49^{\mathrm{a}}$ & $3.44^{\mathrm{a}}$ & $0.05^{\mathrm{b}}$ & $3.26^{\mathrm{ab}}$ & \\
\hline $\mathrm{NE}(\mathrm{N})+\mathrm{FFP}(\mathrm{P}$ and $\mathrm{K})$ & $98.41^{\mathrm{a}}$ & $1.75^{\mathrm{b}}$ & $0.04^{\mathrm{c}}$ & $2.72^{b}$ & \\
\hline GR & $97.75^{\mathrm{a}}$ & $1.48^{\mathrm{bc}}$ & $0.04^{\mathrm{c}}$ & $2.42^{\mathrm{bc}}$ & \\
\hline FFP & $88.39^{\mathrm{b}}$ & $1.29^{\mathrm{c}}$ & $0.04^{\mathrm{c}}$ & $1.75^{\mathrm{c}}$ & \\
\hline $\operatorname{SEM}( \pm)$ & 2.54 & 0.46 & 0.04 & 0.40 & \\
\hline Grand Mean & 95.79 & 2.31 & 0.04 & 2.85 & \\
\hline $\operatorname{LSD}(\mathrm{P}<0.05)$ & $5.78 * *$ & $0.44 * * *$ & $0.01 * *$ & $0.88 * *$ & \\
\hline $\mathrm{CV} \%$ & 3.92 & 12.54 & 8.80 & 20.12 & \\
\hline
\end{tabular}

Note. Significant “*”; Highly significant “**”; Very highly significant “***”, NE= Nutrient export ${ }^{\circledR}, \mathrm{LCC}=$ Leaf color chart, $\mathrm{LAI}=$ Leaf area index

3.2 Yield Attributing Characters (Effective Tillers $\mathrm{m}^{-2}$, Length of Panicle, Weight of Panicle, Number of Grains per Panicle, Fertility, Test Weight and Tiller Panicle Conversion Index)

The result showed significant effect of different precision nutrient management practice on yield attributing characteristic such as effective tillers $\mathrm{m}^{-2}$, length of panicle, weight of panicle, number of grains per panicle, fertility, test weight and tiller panicle conversion index. The number of effective tillers $\mathrm{m}^{-2}$ varied from 206 to 354 being significantly higher in NE than FFP and are statistically at par with $\mathrm{LCC}(\mathrm{N})$ combined with $\mathrm{NE}(\mathrm{PK}), \mathrm{NE}(\mathrm{N})$ combined with FFP(PK) and GR. The maximum panicle length of $26.31 \mathrm{~cm}$ was recorded in nutrient expert recommendation fertilizer dose. The panicle length obtained from LCC(N)combined with $\mathrm{NE}(\mathrm{PK}), \mathrm{NE}(\mathrm{N})$ combined with FFP(PK), GR and FFP are at par with lowest panicle in farmers practice $(20.61 \mathrm{~cm})$. Pertaining to the panicle weight, significantly higher panicle weight $(81.50 \mathrm{~g})$ was obtained from NE followed by GR (78.25 g). Similarly, number of filled grains per panicle was recorded highest in LCC(N)combined with $\mathrm{NE}(\mathrm{PK})$ followed by NE, $\mathrm{NE}(\mathrm{N})$ combined with FFP(PK), GR and FFP respectively. Further, fertility was recorded highest in NE(N) combined with FFP(PK) followed by NE, LCC(N) combined with NE(PK), GR and FFP being FFP the lowest. Test weight and tiller panicle conversion index was recorded lowest (14gm and 50.52 \%) in FFP as compared to other treatments. This is because of balanced supply and availability of NPK fertilizers to the plants. Similar results were reported (Haq et al., 2002; Gupta et al., 2016; Budathoki et al., 2018). 


\section{Macrothink}

Table 3. Effect of different precision nutrient management on yield attributing character in hybrid rice in Lamahi, Dang 2018

\begin{tabular}{llllll}
\hline Treatment & $\begin{array}{l}\text { Effective } \\
\mathrm{m}^{-2}\end{array}$ & $\begin{array}{l}\text { tiller } \\
\text { panicle }(\mathrm{cm})\end{array}$ & $\begin{array}{l}\text { Length of } \\
\text { peight } \\
\text { panicle }(\mathrm{g})\end{array}$ & $\begin{array}{l}\text { of } \\
\text { No of filled } \\
\text { grains }\end{array}$ \\
\hline $\mathrm{NE}$ & $354.50^{\mathrm{a}}$ & $26.31^{\mathrm{a}}$ & $81.50^{\mathrm{a}}$ & $337.00^{\mathrm{b}}$ \\
$\mathrm{LCC}(\mathrm{N})+\mathrm{NE}(\mathrm{P}$ and & $292.00^{\mathrm{a}}$ & $22.00^{\mathrm{b}}$ & $78.00^{\mathrm{b}}$ & $390.00^{\mathrm{a}}$ \\
$\mathrm{K})$ & & & & \\
$\mathrm{NE}(\mathrm{N})+\mathrm{FFP}(\mathrm{P}$ and K) & $347.00^{\mathrm{a}}$ & $21.37^{\mathrm{b}}$ & $77.75^{\mathrm{b}}$ & $318.00^{\mathrm{c}}$ \\
$\mathrm{GR}$ & $319.00^{\mathrm{a}}$ & $22.67^{\mathrm{b}}$ & $78.25^{\mathrm{b}}$ & $240.00^{\mathrm{d}}$ \\
$\mathrm{FFP}$ & $206.50^{\mathrm{b}}$ & $20.61^{\mathrm{b}}$ & $72.50^{\mathrm{c}}$ & $219.00^{\mathrm{e}}$ \\
\hline $\mathrm{SEM}( \pm)$ & 2.33 & 1.03 & 1.48 & 2.59 \\
Grand Mean & 303.80 & 22.59 & 77.60 & 301.05 \\
LSD $(\mathrm{P}<0.05)$ & $73.11^{* *}$ & $2.07^{* * *}$ & $2.19^{* * *}$ & $9.62^{* * *}$ \\
$\mathrm{CV} \%$ & 15.62 & 5.95 & 1.83 & 2.07 \\
\hline
\end{tabular}

Note. Significant “*”; Highly significant “**”; Very highly significant “***”, NE= Nutrient export $\AA, G R=$ Government recommendation, FFP $=$ Farmers fertilizer Practice

Table 4. Effect of different precision nutrient management on yield attributing character in hybrid rice in Lamahi, Dang 2018

\begin{tabular}{llll}
\hline Treatments & Fertility $(\%)$ & Test weight $(\mathrm{g})$ & $\begin{array}{l}\text { Tiller } \\
\text { conversion index (\%) }\end{array}$ \\
\hline NE & $87.56^{\mathrm{b}}$ & $15.75^{\mathrm{ab}}$ & $73.05^{\mathrm{a}}$ \\
LCC $(\mathrm{N})+\mathrm{NE}(\mathrm{P}$ and K) & $88.12^{\mathrm{b}}$ & $17.00^{\mathrm{a}}$ & $64.57^{\mathrm{b}}$ \\
$\mathrm{NE}(\mathrm{N})+$ FFP $(\mathrm{P}$ and K) & $90.52^{\mathrm{a}}$ & $17.00^{\mathrm{a}}$ & $56.85^{\mathrm{c}}$ \\
GR & $77.55^{\mathrm{c}}$ & $15.00^{\mathrm{bc}}$ & $55.28^{\mathrm{c}}$ \\
FFP & $67.24^{\mathrm{d}}$ & $14.00^{\mathrm{c}}$ & $50.52^{\mathrm{d}}$ \\
\hline SEm $( \pm)$ & 4.02 & 0.61 & 3.69 \\
Grand Mean & 82.20 & 15.75 & 60.05 \\
LSD $(\mathrm{P}<0.05)$ & $2.10^{* * *}$ & $1.24^{* * *}$ & $2.78^{* * *}$ \\
CV\% & 1.66 & 5.11 & 3.01 \\
\hline
\end{tabular}

Note. Significant “*”; Highly significant “**”; Very highly significant “***”, NE= Nutrient export ${ }^{\circledR}, \mathrm{GR}=$ Government recommendation, $\mathrm{FFP}=$ Farmers fertilizer Practice

\subsection{Yield Parameter (Grain Yield, Straw Yield, biological yield and Harvest Index)}

The research revealed that grain yields of rice varied significantly due to various SSNM treatments. The highest grain yield of rice (6.36 ton ha ${ }^{-1}$ ) was recorded in NE being highly significant over GR and FFP but remained at par with the grain yield obtained under LCC (N)combined with NE (PK) followed by $\mathrm{NE}(\mathrm{N})$ combined with $\operatorname{FFP}(\mathrm{PK})$. The highest straw yield of 12.62 ton $\mathrm{ha}^{-1}$ was obtained from NE treatment which was significantly superior over other treatments GR $\left(9.47\right.$ ton $\left.\mathrm{ha}^{-1}\right)$ and FFP $\left(9.50\right.$ ton ha $\left.^{-1}\right)$ treatments but remained at par with 


\section{Macrothink}

LCC (N) combined with NE(PK) (12.87 ton $\mathrm{ha}^{-1}$ ) and NE(N) combined with FFP(PK) (10.82 ton $\left.\mathrm{ha}^{-1}\right)$. Highest biological yield was obtained from the LCC(N) combined with NE(PK) (18.55 ton $\mathrm{ha}^{-1}$ ). The lowest biological value obtained in GR and FFP at a statistically par (15.65 ton $\mathrm{ha}^{-1}$ and 15.62 ton $\mathrm{ha}^{-1}$ ). Significantly highest harvest index was obtained from NE fertilizer recommendation (41.38\%) followed by LCC(N) combined with NE(PK) $(39.57 \%)$ followed by $\mathrm{NE}(\mathrm{N})$ combined with $\mathrm{FFP}(\mathrm{PK})$ and GR $(35.21 \%$ and $33.93 \%)$ respectively. The lowest harvest index was obtained from farmer practice $(28.73 \%)$. These results are in conformity with findings of other researchers (Kabir et al., 2011, Dobermann et al., 2003, Biradar et al., 2006).

Table 5. Effect of different precision nutrient management on yields in hybrid rice in Lamahi, Dang 2018

\begin{tabular}{|c|c|c|c|c|}
\hline Treatments & $\begin{array}{l}\text { Grain yield } \\
\left(\text { ton } \mathrm{ha}^{-1}\right)\end{array}$ & $\begin{array}{l}\text { Straw yield } \\
\left(\text { ton } \mathrm{ha}^{-1}\right)\end{array}$ & $\begin{array}{l}\text { Biological } \\
\text { yield (ton } \mathrm{ha}^{-1} \text { ) }\end{array}$ & $\begin{array}{l}\text { Harvest index } \\
(\%)\end{array}$ \\
\hline $\mathrm{NE}$ & $6.36^{\mathrm{a}}$ & $12.62^{\mathrm{a}}$ & $18.22^{\mathrm{a}}$ & $41.38^{\mathrm{a}}$ \\
\hline $\begin{array}{l}\mathrm{LCC}(\mathrm{N})+\mathrm{NE}(\mathrm{P} \text { and } \\
\mathrm{K})\end{array}$ & $6.17^{\mathrm{a}}$ & $12.87^{\mathrm{a}}$ & $18.55^{\mathrm{a}}$ & $39.57^{\mathrm{ab}}$ \\
\hline $\begin{array}{l}\mathrm{NE}(\mathrm{N})+\mathrm{FFP}(\mathrm{P} \text { and } \\
\mathrm{K})\end{array}$ & $5.84^{\mathrm{ab}}$ & $10.82^{\mathrm{ab}}$ & $16.15^{\mathrm{ab}}$ & $35.21^{\mathrm{bc}}$ \\
\hline GR & $5.20^{\mathrm{b}}$ & $9.47^{\mathrm{c}}$ & $15.65^{b}$ & $33.93^{c}$ \\
\hline FFP & $5.13^{\mathrm{b}}$ & $9.05^{\mathrm{c}}$ & $15.62^{\mathrm{b}}$ & $28.73^{\mathrm{d}}$ \\
\hline $\operatorname{SEm}( \pm)$ & 0.29 & 0.83 & 2.40 & 2.31 \\
\hline Grand Mean & 5.7445 & 10.97 & 16.84 & 35.76 \\
\hline $\operatorname{LSD}(\mathrm{P}<0.05)$ & $0.67 * *$ & $2.36^{*}$ & $2.36^{*}$ & $4.54 * * *$ \\
\hline $\mathrm{CV} \%$ & 7.61 & 13.96 & 9.11 & 8.24 \\
\hline
\end{tabular}

Note. Significant “*”; Highly significant “**”; Very highly significant “***”, NE= Nutrient export ${ }^{\circledR}, \mathrm{GR}=$ Government recommendation, $\mathrm{FFP}=$ Farmers fertilizer Practice

\subsection{Comparison of Increase in Grain Yield Over FFP}

The study showed that NE based nutrient management can produce 1.23 ton ha ${ }^{-1}$ more grain yield than the existing FFP which is equivalent to $23.97 \%$ increase in yield. Similar results was recorded by Shrestha et al. (2018). 


\section{1) Macrothink}

Table 6. Effect of different precision nutrient management on grain yield over FFP in hybrid rice in Lamahi, Dang 2018

\begin{tabular}{llcll}
\hline Treatments & $\begin{array}{l}\text { Grain } \\
\left.\mathrm{ha}^{-1}\right)\end{array}$ & yield & $\begin{array}{l}\text { (ton } \\
\text { FFP }\left(\text { ton } \mathrm{ha}^{-1}\right)\end{array}$ & $\begin{array}{l}\text { Increase in yield } \\
\text { over FFP }(\%)\end{array}$ \\
\hline NE & 6.36 & 1.23 & 23.97 \\
LCC $(\mathrm{N})+\mathrm{NE}(\mathrm{P}$ and K) & 6.17 & 1.04 & 20.27 \\
$\mathrm{NE}(\mathrm{N})+$ FFP $(\mathrm{P}$ and K) & 5.84 & 0.71 & 13.84 \\
GR & 5.20 & 0.07 & 1.36 \\
FFP & 5.13 & - & - \\
\hline
\end{tabular}

Note. $\mathrm{NE}=$ Nutrient export ${ }^{\circledR}, \mathrm{LCC}=$ Leaf Color Chart $\mathrm{GR}=$ Government recommendation, $\mathrm{FFP}=$ Farmers fertilizer Practice

3.4.1 Comparison of Nutrient Expert Estimated Attainable Rice Yield Versus Actual Rice Yield

The comparative figure of NE-simulated yield and the actual observed yields recorded in the farmer field indicates that NE-based fertilizer recommendations formulated by the software proved to be zestful to reach the yield targets. The NE-simulated target yield was 6.55 ton $\mathrm{ha}^{-1}$ and yield in farmer's field was 5 ton ha ${ }^{-1}$ respectively. While, the corresponding average actual yield observed was 6.36 ton $\mathrm{ha}^{-1}$ and 5.13 ton $\mathrm{ha}^{-1}$ respectively. This illustrates that the fertilizer recommendations developed by NE had attained the targeted attainable yields. A similar result was accorded in Karnataka state of India by Majumdar et al. (2013).

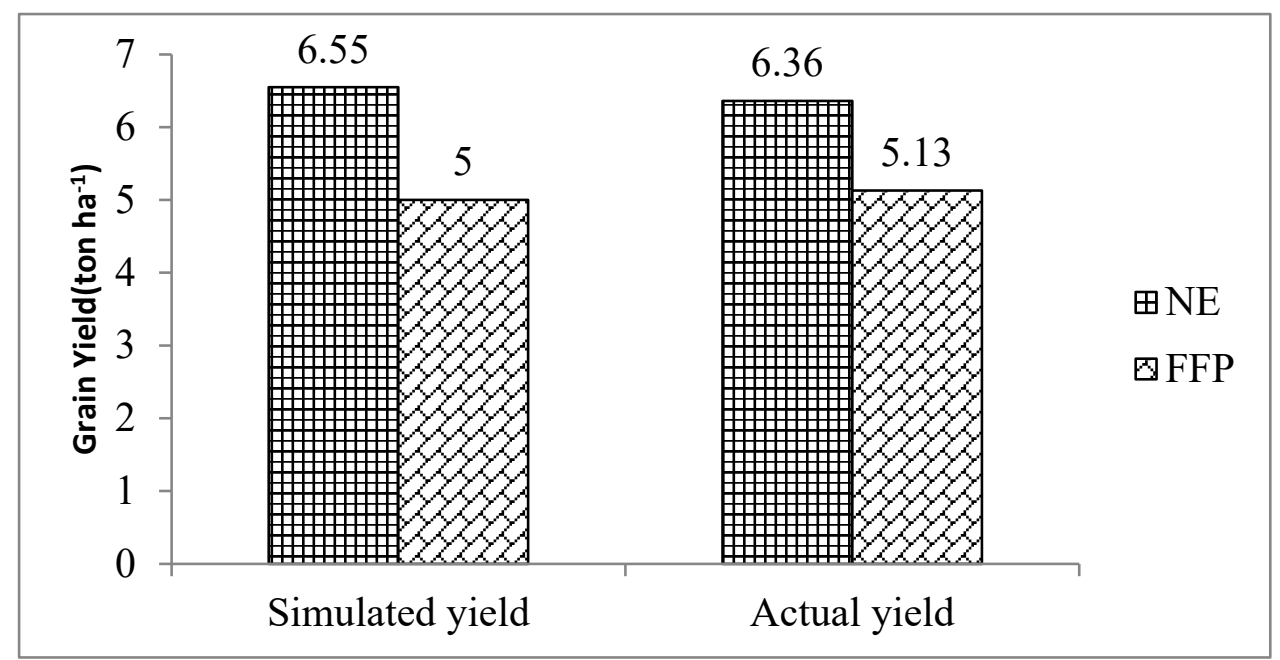

Figure 1. Comparison of precision nutrient management treatments in stimulated and observed yield in hybrid rice in Lamahi, Dang 2018 


\subsubsection{Profitability Ratios of Different Nutrient Practices in Hybrid Rice Production}

Economic analysis of different treatments showed that the highest gross return was obtained from NE (Rs 242498) followed by NE(N) combined with FFP(PK) (Rs 206211). The gross revenue from GR and LCC $(\mathrm{N})$ combined with $\mathrm{NE}(\mathrm{PK})$ are at par and was greater than FFP. The lowest gross revenue is obtained from FFP (Rs 151395). The highest net revenue was obtained from NE(N) combined with FFP(PK) (Rs 7925) followed by NE and LCC(N) combined with $\mathrm{NE}(\mathrm{PK})$ (both statistically at par). Though the cost of cultivation is higher in NE than other management practices, the gross and net revenue is higher, because of higher grain and straw yield. The highest B: C ratio was obtained in NE (3.08) whereas lowest B: C ratio was obtained from treatment GR dose. Hence highest B: C ratio of NE shows its superiority amongst the others. Similar result was found by IRRI (2010).

The results depicted that highest PFP was obtained from NE (1.92) which is at par with GR management practice (1.91). The PFP of both LCC(N) combined NE(PK) and $\mathrm{NE}(\mathrm{N})$ combined FFP(PK) are at par being slightly lower than the highest. Similarly, TFP was significantly highest in NE (0.49) followed by LCC(N) combined NE(PK) (0.48). PFP measures normally show higher rates of growth than TFP because growth in productivity could result from more intensive use of inputs, including fertilizer and machinery, rather than TFP increase.

Table 7. Effect of different precision nutrient management on profitability ratios in hybrid rice in Lamahi, Dang 2018

\begin{tabular}{llllll}
\hline Treatment & $\begin{array}{l}\text { Gross } \\
\text { Revenue } \\
\left(\mathrm{NRs} \mathrm{ha}^{-1}\right)\end{array}$ & $\begin{array}{l}\text { Net } \\
\text { Revenue } \\
\left(\mathrm{NRs} \mathrm{ha}^{-1}\right)\end{array}$ & B:C ratio & $\begin{array}{l}\text { Partial } \\
\text { factor } \\
\text { productivity }\end{array}$ & $\begin{array}{l}\text { Total factor } \\
\text { productivity }\end{array}$ \\
\hline NER & $242498^{\mathrm{a}}$ & $64188^{\mathrm{ab}}$ & $3.08^{\mathrm{a}}$ & $1.92^{\mathrm{a}}$ & $0.49^{\mathrm{a}}$ \\
$\mathrm{LCC}(\mathrm{N})+\mathrm{NE}(\mathrm{P}$ and & $177761^{\mathrm{c}}$ & $62302^{\mathrm{ab}}$ & $2.26^{\mathrm{c}}$ & $1.40^{\mathrm{b}}$ & $0.48^{\mathrm{a}}$ \\
$\mathrm{K})$ & & & & & \\
$\mathrm{NE}(\mathrm{N})+$ FFP (P and & $206211^{\mathrm{b}}$ & $75925^{\mathrm{a}}$ & $2.61^{\mathrm{b}}$ & $1.51^{\mathrm{b}}$ & $0.35^{\mathrm{b}}$ \\
$\mathrm{K})$ & & & & & \\
$\mathrm{GR}$ & $173286^{\mathrm{c}}$ & $58380^{\mathrm{b}}$ & $2.02^{\mathrm{d}}$ & $1.91^{\mathrm{a}}$ & $0.40^{\mathrm{ab}}$ \\
FFP & $151395^{\mathrm{d}}$ & $51499^{\mathrm{b}}$ & $2.26^{\mathrm{c}}$ & $1.70^{\mathrm{ab}}$ & $0.31^{\mathrm{b}}$ \\
\hline SEm $( \pm)$ & 1.7328 & 3.842496 & 0.17 & 0.04 & 0.13 \\
Grand Mean & 190230.8 & 62459.35 & 2.44 & 1.6915 & 0.41 \\
LSD & $19699.41^{* * *}$ & $13618.16^{*}$ & $0.05^{* * *}$ & $0.34^{*}$ & $0.11^{*}$ \\
$\mathrm{CV} \%$ & 6.72 & 14.15 & 1.41 & 13.41 & 18.47 \\
\hline
\end{tabular}

Note. Significant “*”; Highly significant “**”; Very highly significant “***”

\section{Conclusions}

Comparative analysis of different precision nutrient management practices showed that 


\section{Macrothink}

Nutrient Expert ${ }^{\circledR}(\mathrm{NE})$ was superior among the rest 5 treatments in terms of growth, yield attributing characters, yield and economic analysis followed by $\mathrm{LCC}(\mathrm{N})$ combined with $\mathrm{NE}(\mathrm{PK})$. NE has increased grain yield by $23.97 \%$ than FFP while $22.30 \%$ than GR whereas straw yield increased by $39.44 \%$ compared to FFP. Physical optimum yield obtained was higher in NE dose where Economic optimum yield was higher in NE(N) combined FFP(PK). Thus, From the research it can be concluded that the precision nutrient management practice using Nutrient Expert ${ }^{\circledR}$ (NE)as a decision tool has brought significant positive effect on hybrid rice production as it make use of the right source of fertilizer, at right time, in right amount and in right place and fulfilled the growing demand for rice.

\section{Acknowledgment}

We express our warmest appreciation towards Prithu Technical College, IAAS for providing platform and immense support.

\section{References}

Biradar, D. P., Aladakatti, Y. R., Rao, T., \& Tiwari, K. W. (2006). Site specific nutrient management for maximization of crop productivity in northern Karnataka. Better Crops Intl., 90(3), 33-35.

Budhathoki, S., Amgain, L.P., Subedi, S., Iqbal, M., Shrestha, N., \& Aryal, S. (2018). Assessing Growth, Productivity and Profitability of Drought Tolerant Rice Using Nutrient Expert - Rice and Other Precision Fertilizer Management Practices in Lamjung, Nepal. Acta Scientific Agriculture, 2(8), 153-158.

Chaturvedi, I. (2005). Effect of Nitrogen Fertilizers on Growth, Yield and Quality of Hybrid Rice (Oryza sativa L.). Central European Journal of Agriculture, 6, 611-618.

Doberman, A. S., \& Witt, C. (2004). The evolution of site specific management in irrigated rice system of Asia (p. 410).

Dobermann, A., \& Witt. C. (2003). Increasing Productivity of Intensive Rice Systems through Site Specific Nutrient Management. Science Publishers and International Rice Research Institute (IRRI), New Delhi, India and Makati City, Philippines.

Ginigaddara Sanjeewanie, S., \& Ranamukharachchi, S. L. (2011). Performance of rice varieties under machine transplanting with different aged seedlings. Recent Research in Science and Technology, 3(3), 76-88.

Gupta, G., Shrestha, A., \& Amgain, L. P. (2016). Evaluation of Different Nutrient Management Practice in Yield and Growth in Rice in Morang District. Adv Plants Agric Res, 3(6), 00119. https://doi.org/10.15406/apar.2016.03.00119

Haq, M. T., Sattar, M. A., \& Hasain, M. M. (2002). Effects of fertilizers and pesticides on growth and yield of rice. Online Journal of Biological Sciences, 2(2), 84-88. https://doi.org/10.3923/jbs.2002.84.88

Heisey, P. W., Morris, M. L., Byerlee, D., \& Lopez-Pereira, M. A. (1998). Economics of hybrid 
maize adoption. In M. L. Morris (Ed.) Maize seed industries in developing countries, Mexico.

IRRI. (2010). Site specific nutrient management. International Rice Research Institute, Los Banos Launga, PhIlippines.

Janssen, B. H., Guiking, F. C .T., Van der Eijk, D., Smaling, E. M. A., Wolf, J., \& Van Reuler., H. (1990). Geoderma, 46, 299-318. https://doi.org/10.1016/0016-7061(90)90021-Z

Kabir, M., Biswas, B. K., Talukder, N. M., \& Mahmud, H. (2011). Total Nutrient Uptake by Grain plus Straw and Economic of Fertilizer Use of Rice Mutation STL-655 Grown under Boro Season in Saline soil. J. Environ. Sci. \& Natural Resources, 4(2), 83-87. https://doi.org/10.3329/jesnr.v4i2.10139

Ladha, J. K., Dawe, D., Pathak, H., Padre, A. T., Yadav, R. L., \& Singh, B. (2003). Improving the productivity and sustainability of rice-wheat systems: Issues and Impacts. Field Crops Res., 81, 159-180. https://doi.org/10.1016/S0378-4290(02)00219-8

Majumdar, K., Satyanarayana, T., Pampolino, M., Dutta, S., Jat, M. L, Sulewski, G., \& Jhonston, A. M. (2013). Nutrient Expert ${ }^{\circ}$ for Hybrid Maize (version 1.1). A decision support tool for providing field specific fertilizer recommendations for tropical hybrid maize. International Plant Nutrition Institute and International Maize and Wheat Improvement Center, India.

MoAD. (2015). Rice Varietal Mapping in Nepal: Implication For Development and Adoption. Ministry of Agricultural Development, Crop Development Directorate, Hariharbhawan Lalitpur.

MoAD. (2017). Krishi Diary. Ministry of agriculture and livestock development, Agriculture information and training centre, Hariharbhawan, Lalitpur.

MOF. (2017/18). Annual Progress report. Ministry of Finance. Government of Nepal.

Muthayya, S., Sugimoto, J. D., Montgomery, S., \& Maberly, G. F. (2014). An Overview OfGlobal Rice Production, Supply, Trade, and Consumption. Annals of the New York Academy of Sciences, 1324(1), 7-14. https://doi.org/10.1111/nyas.12540

Pampolino, M. F., Manguiat, I. J., Ramanathan, S., Gines, H. C., Tan, P. S., Chi, T. T. N., ... Buresh, R. J. (2007). Environmental impact and economic benefits of site- specific nutrient management (SSNM) in irrigated rice systems. Agriculltural Systems Journal, 93, 1-24. https://doi.org/10.1016/j.agsy.2006.04.002

Shrestha, S., Amgain, L. P., Subedi, R., \& Sahi, S. (2018). Productivity and Profitability Analysis of old aged hybrid rice seedling using nutrient expert and other precision nutrient management practices at Lamjung, Nepal. International Journal of Applied sciences and Biotechnology, 6(3), 232-237. https://doi.org/10.3126/ijasbt.v6i3.20494

Singh, S. S. (2004). Soil fertility and nutrient management. Kalyani Publishers, Ludhiana, India 


\section{Macrothink

\section{Copyright Disclaimer}

Copyright reserved by the author(s).

This article is an open-access article distributed under the terms and conditions of the Creative Commons Attribution license (http://creativecommons.org/licenses/by/3.0/). 